\title{
СУЧАСНА СОЦАЛЬНО-ЕКОНОМІЧНА МОДЕЛЬ ДЕРЖАВИ ЗАГАЛЬНОГО ДОБРОБУТУ
}

\section{Романченко В. Б.}

\section{ВСТУП}

Серед сучасних соціально-економічних моделей важливе місце посідає модель «держави загального добробуту» (welfare state), яка була однією з базових соціально-економічних моделей XX століття ${ }^{1}$. За минуле століття ця модель отримала глобальне поширення та зазнала значних змін: становлення, різні варіанти реалізації та впровадження моделі, «золоте століття», кризу парадигми, посткризовий розвиток². $€$ багато публікацій та досліджень, які вказують про відхід або навіть про «демонтаж» держави загального добробуту, про необхідність перегляду та зміни іiї економічної основи. Інші ж, навпаки, показують необхідність збереження «держави загального добробуту», адже лише за такої моделі соціально-економічної політики можливо забезпечити належні гарантії соціального захисту громадян ${ }^{3}$.

Серед причин, що призвели до «втрати популярності» цієї моделі, дослідники вказують такі як: глобалізація, демографічний зсув (пов'язаний зі старінням населення), соціальний зсув (пов'язаний 3 глобальним трендом від солідарності до індивідуалізму) ${ }^{4}$, економічний тягар забезпечення соціальних гарантій, моральний ризик (прояви утриманства) та інституційні зміни у суспільстві ${ }^{5}$. Тому «криза» держави загального добробуту в 1980-2000 роках зумовила необхідність перегляду головних постулатів моделі та критичних зауважень на іiі адресу. Але тут важливо зазначити, що питання конфігурації сучасної

1 Романченко В.Б. Порівняльний аналіз сучасних соціально-економічних моделей держави. Інвестиції: практика та досвід. 2020. № 19-20. С. 186-199. DOI: 10.32702/2306-6814.2020.19-20.186.

2 Сидорина Т.Ю. Партнерство государства и институтов самоорганизации граждан в реализации социальной политики (теоретический аспект). Terra Economicus. 2010. № 8 (1). C. 117-129.

3 Чулицкая Т. Демонтаж государства всеобщего благосостояния. Палітычная сфера. 2005. № 4. С. 61-67.

${ }^{4}$ Там само.

${ }^{5}$ Сидорина Т.Ю. Операция "Welfare State": решило ли государство всеобщего благосостояния проблемы идеального государства? Terra Economicus. 2012. № 10 (3). C. 84-99. 
держави загального добробуту у XXI столітті є частиною більш загальної дискусії щодо ролі та місця ринку, держави та «громадянського суспільства» (як форми недержавних спільних дій) ${ }^{6}$.

У будь-якому разі говорити про остаточний занепад та відхід від концепції «держави загального добробуту» $\epsilon$ передчасним та неправильним. Важливим фактором під час аналізу впливу зазначених причин щодо застосування політики «держави загального добробуту» $€$ те, що нині, окрім інституту держави, у світі не має жодного суб'єкта, який би міг виступати гарантом соціальних прав та можливостей для своїх громадян. Лише держава здатна дозволити собі таку «неефективну» діяльність, як забезпечення благополуччя населення ${ }^{7}$. Більш того, в тих країнах, які досягли кращого функціонування соціальних механізмів, таких як країни Скандинавії, ринки також працюють краще. Це дозволяє зробити припущення, що добре функціонуюча «держава загального добробуту» може сприяти функціонуванню ринку ${ }^{8}$. Тому дослідники стверджують, що віджила себе не сама концепція держави загального добробуту, а її конкретна історична форма ${ }^{9}$.

Нині процес трансформації моделі став результатом багатьох чинників: 3 одного боку, це краще розуміння економічної теорії та природи «провалів ринку та держави»; з іншого - це намагання зробити інструменти цієї моделі більш ефективними.

Досвід різних країн світу показує, що сама класична модель «держави загального добробуту» в процесі трансформації також інкорпорувала у себе елементи інших моделей: неоліберальної та наздоганяючої моделі ${ }^{10}$. $€$ багато інституцій, законів і програм, які формують державу загального добробуту, та багато з них перетинаються з іншими інструментами, що застосовуються в інших моделях ${ }^{11}$.

Не в останню чергу на процес зміни моделі впливають сучасне розуміння поняття «добробут» та нові виклики, які постали перед державою у забезпеченні соціального захисту та благополуччя

${ }^{6}$ Stiglitz J.E. The Welfare State in the Twenty-First Century. Working Papers of Roosevelt Institute; Climate and Economic Transformation. 2017. June, 20.

7 Чулицкая Т. Демонтаж государства всеобщего благосостояния. Палітычная сфера. 2005. № 4. С. 61-67.

${ }^{8}$ Stiglitz J.E. The Welfare State in the Twenty-First Century. Working Papers of Roosevelt Institute; Climate and Economic Transformation. 2017. June, 20.

${ }^{9}$ Русаков В.М., Саранчин Ю.К. Социальное государство: кризис или закат? Современные исследования социильных проблем. 2012. № 11 (19).

${ }^{10}$ Фомін С.С. Типи соціально-економічних моделей та їхній вплив на процеси модернізації. Країни пострадянського простору: виклики модернізації : зб. наук. пр. 2016. C. $32-46$.

11 Stiglitz J.E. The Welfare State in the Twenty-First Century. Working Papers of Roosevelt Institute; Climate and Economic Transformation. 2017. June, 20. 
населення. Наприклад, жодна з інших поширених сучасних соціальноекономічних моделей не приділяє стільки уваги проблемам довкілля, як модель «держави загального добробуту».

Отже, питання, які будуть висвітлюватися у цій статті, можна сформулювати таким чином:

- якою повинна бути сучасна держава загального добробуту?

- які ії основні функції нині?

- які механізми та інструменти потрібно використати для виконання цих функцій.

\section{1. Концептуальна основа сучасної держави загального добробуту}

Більшість дослідників пов'язують виникнення та становлення соціально-економічної моделі «держави загального добробуту» з явними невдачами в економіці та суспільстві, наслідки яких ставали соціально неприйнятними. Через це класичний варіант такої моделі зосереджувався на певному наборі «ринкових невдач», пов'язаних із нездатністю ринків допомогти людям упоратись 3 важливими труднощами, 3 якими вони стикаються, такими як забезпечення соціального захисту, пенсійного страхування (пенсійних ануїтетів) та страхування здоров'я. Ринки також нездатні забезпечити належний захист від безробіття та інвалідності, що підсилюе потребу у механізмах «держави загального добробуту». Розвиток економічної теорії допоміг пояснити, чому ці «ринкові невдачі» слід було очікувати ${ }^{12}$.

У зв'язку 3 цим основоположною, хоч i менш зрозумілою, причиною збереження моделі «держави загального добробуту» $\epsilon$ необхідність урегулювання провалів ринку. Ринки можуть бути неефективними 3 багатьох причин, які розглядалися в авторитетних працях з економіки інформації, поведінкової економіки, неповних ринків, неповних договорів і оптимального оподаткування ${ }^{13}$. Усе це покращує розуміння економічної теорії в питаннях обмеження ринків та індивідуальної раціональності, важливості рівності, і має відновити увагу до моделі держави загального добробуту разом з переосмисленням того, що вона має робити і як вона має це робити. Модель держави загального добробуту XXI століття полягає у досягненні справедливого суспільства та поліпшенні добробуту звичайних громадян, визнаючи, що ринки самі по собі не обов'язково це зроблять,

${ }^{12}$ Там само.

13 Барр Н. Смена течений. В условиях глубоких социальных изменений государство всеобщего благосостояния необходимо, как никогда прежде. Финансы и развитие : ежеквартальный журнал МВФ. 2018. Декабрь. С. 16-19. 
a інтереси бізнесу та національні інтереси (інтереси звичайних громадян) часто помітно відрізняються. Сучасний варіант моделі держави загального добробуту - це більше ніж просто захисна мережа, що забезпечує мінімальні умови гідного життя. Традиційна держава загального добробуту була зосереджена на соціальному захисті компенсації за провали ринку. Але сучасна ії модель є більш ніж такою: вона також $є$ системою захисту споживачів, інвесторів і працівників, включаючи систему, що намагається підвищити конкурентоспроможність і прозорість ринків ${ }^{14}$. Таким чином, концепція «держави загального добробуту», яка раніше здебільшого розглядалась з боку дихотомії «держава проти ринку» ${ }^{15}$, трансформувалась у принцип: «дії держави та ринку мають підсилювати один одного» ${ }^{16}$.

Окрім базової причини збереження й трансформації моделі «держави загального добробуту», яка пов'язана 3 необхідністю урегулювання провалів ринку, $\epsilon$ й інші тенденції у соціальноекономічному середовищі, які впливають на конфігурацію сучасного варіанту моделі.

Насамперед це зміни, які пов'язані із ринком праці. Нині «довічна» зайнятість перестала бути нормою, ринки праці стають усе більш нестійкими, бурхливий технологічний прогрес вимагає від працівників безперервного освоєння нових навичок, відбулася зміна ролей у сімейних відносинах: чоловік $\mathrm{i}$ дружина стали рівноцінними годувальниками ${ }^{17}$. Більш того, відбулась трансформація самого поняття «труд»: якщо раніше під цією категорією розуміли діяльність, що була пов'язана із забезпеченням індивіду необхідних життєвих потреб, то сьогодні праця - це діяльність, яка дозволяє індивіду реалізувати свій потенціал. Сукупність цих факторів призвела до того, що сьогодні ринок праці змінюється дуже стрімко та сучасні наймані працівники вимагають усе більшої гнучкості та свободи у виконанні власної роботи. I до всього цього варто додати природне бажання приватних компаній (а іноді й не тільки приватних) скоротити свої витрати за

${ }^{14}$ Stiglitz J.E. The Welfare State in the Twenty-First Century. Working Papers of Roosevelt Institute; Climate and Economic Transformation. 2017. June, 20.

15 Сидорина Т.Ю. Партнерство государства и институтов самоорганизации граждан в реализации социальной политики (теоретический аспект). Terra Economicus. 2010. № 8 (1). C. 117-129.

16 Барр Н. Смена течений. В условиях глубоких социальных изменений государство всеобщего благосостояния необходимо, как никогда прежде. Финансы и развитие : ежеквартальный журнал МВФ. 2018. Декабрь. С. 16-19.

17 Барр Н. Смена течений. В условиях глубоких социальных изменений государство всеобщего благосостояния необходимо, как никогда прежде. Финансы и развитие : ежеквартальный журнал МВФ. 2018. Декабрь. С. 16-19. 
рахунок зниження витрат на фонд оплати праці. Ці процеси призвели до зростання нових форм зайнятості на основі онлайн-платформ (гігекономіка), які також суттєво трансформують ринок праці та систему соціального забезпечення. Розвиток сектору гіг-економіки спричиняє нову нерівність серед робітників 3 різним рівнем захисту, який надається працівникам онлайн-платформами. Такі працівники мають обмежений доступ до соціальних схем захисту власних інтересів порівняно з гарантованим захистом традиційних працівників. Тому подібні зміни лише підсилюють потребу в універсальних підходах моделі держави загального добробуту.

У минулому столітті шлюби були переважно стійкими та основним ризиком для сім'ї була смерть годувальника. У наші дні все більше жінок отримують освіту і мають оплачувану роботу, а структура сім’і стала більш різноманітною. Ці зміни вказують на необхідність заходів політики, які розширюють можливості вибору між оплачуваною роботою і сімейними обов'язками, включаючи догляд за дітьми, і таких заходів політики, що підвищують гендерну рівність (зокрема, закон про рівну оплату праці) ${ }^{18}$. Це також зумовлює потребу у використанні механізмів «держави загального добробуту» та покладає на цю модель нові вимоги.

Трансформація «держави загального добробуту» пов'язана не лише 3 розвитком економічних доктрин і зміною підходів до гарантування добробуту населення. Якщо на початку ії становлення (перша половина $\mathrm{XX}$ ст.) ішлося про «добробут» лише як грошовий дохід, то зараз це поняття розширилось та охоплює, окрім доходу родини й базових соціальних сервісів, ступінь задоволення побутових, культурних і духовних потреб (соціальна безпека, якість житла й відпочинку, час на дозвілля, стан навколишнього природного середовища, соціальні контакти, політичне представництво тощо). 3 огляду на розширення поняття «добробут» трансформація «держави загального добробуту» виключно за рахунок сучасних і модернізованих економічних доктрин не $\epsilon$ повноцінною ${ }^{19}$. Одним 3 варіантів трансформації «осердя» моделі «держави загального добробуту» у напрямі становлення еко-соціальної ринкової економіки є концепція «сталого добробуту». I хоча iї розроблення має теоретизований характер, вона актуалізує низку важливих питань, що потребують практичного вирішення. Серед них -

18 Барр Н. Смена течений. В условиях глубоких социальных изменений государство всеобщего благосостояния необходимо, как никогда прежде. Финансы и развитие : ежеквартальный журнал МВФ. 2018. Декабрь. С. 16-19.

${ }^{19}$ Стиглиц Д., Сен А., Фитусси Ж.-П. Неверно оценивая нашу жизнь: Почему ВВП не имеет смысла? Доклад Комиссии по измерению эффективности экономики и социального прогресса. Москва : Изд-во Института Гайдара. 2016. 216 с. 
визнання критичних рівнів і обмежень у добробуті та споживанні, а також необхідність перегляду (i, можливо, певного обмеження) потреб, прагнень і бажань людей ${ }^{20}$.

Сукупність усіх цих чинників і визначає сучасну конфігурацію соціально-економічної моделі «держави загального добробуту»: модель, яка спрямована на всебічний розвиток кожного громадянина завдяки ефективному розподілу стандартних (фінансовоматеріальних) і нетипових благ (культурних, політичних, екологічних), що забезпечується синергією ринкового саморегулювання та державного втручання.

\section{2. Основні функції сучасної держави загального добробуту}

Конфігурація сучасного варіанту соціально-економічної моделі «держави загального добробуту» визначає іії основні функції. Головна функція тепер полягає не у виправленні «провалів ринку», а у створенні умов, за яких ці провали є малоймовірними. Такий підхід обгрунтовує чому сучасна модель має значно більший вплив порівняно із традиційною моделлю «держави загального добробуту» у шести важливих напрямах ${ }^{21}$ :

1) Ризики та інноваиії. Як прийнято вважати, недосконалість ринків та їх ризики можуть послабити здатність і бажання людей здійснювати ризиковані інвестиції, у тому числі в інновації. Ретельно продумана система держави загального добробуту може спонукати людей випробовувати нові можливості у нових сферах та бути більш відкритими до змін ${ }^{22}$. Таким чином, згадувана модель не тільки призводить до кращих результатів у рамках звичайної статичної моделі, але й сприяє становленню більш динамічної та інноваційної економіки.

2) Краӥна як спільнота: соиіальна солідарність. Так само як у сім'ї піклуються один про одного, тому що є солідарність між членами сім'ї, так само й модель «держави загального добробуту» передбачає відношення до суспільства як до великої сім’ї: національна солідарність означає, що ті, хто може допомогти, піклуються про тих, кому менше пощастило. Принаймні, вони забезпечують певну форму соціального захисту. Сім'ї (або спільноти) діють за зовсім іншими принципами, ніж ринки. Навіть якщо $є$ деяка взаємна узгодженість, немає чітко визначеного quid pro quo (послуга за послугу, плата за

${ }^{20}$ Koch M. Sustainable Welfare, degrowth and eco-social policies in Europe. Social Policy in the European Union: State of Play. Bruxelles : European Trade Union Institute. 2018. P. 35.

${ }^{21}$ Stiglitz J.E. The Welfare State in the Twenty-First Century. Working Papers of Roosevelt Institute; Climate and Economic Transformation. 2017. June, 20.

${ }^{22}$ Чанг Х.-Ю. 23 приховані факти про капіталізм. Київ : Наш Формат, 2018. 296 с. 
плату). Вважається, що етичні норми - регулятивні відносини, а не якась абстрактна цінова система. Як показує практика, ринок працює краще, коли суб'єкти, які в ньому беруть участь, керуються «сильними нормами», наприклад «обман» чи «відповідальність» у виконанні контракту (для прикладу варто згадати про дослідження впливу неекономічної категорії «довіра» на роботу економічної системи). Коли ж стає дуже дорого виконувати контракти відповідно до закону, то ринки руйнуються через наявність великих «обманів». Закон, по суті, розроблений частково для того, щоб підсилити «добрі» норми та суворо покарати тих, хто занадто відходить від цих норм. Ефективно працююча модель «держави загального добробуту» допомагає закріпити «добрі» норми саме через національну солідарність та єдність суспільства.

3) Ендогенні (внутрішньосистемні) переваги. Організація суспільства, включаючи правила економічної поведінки, впливає на природу особистості, iï переконання, уподобання та поведінку. «Держава загального добробуту» заохочує соціальну солідарність, змушуючи індивіда більше думати про спільноту, частиною якої він $\epsilon, \mathrm{i}$ таким чином покращуючи соціальну поведінку у безліч інших способів.

4) Сочіальна справедливість. Будь-який варіант соціальноекономічної моделі «держави загального добробуту» зорієнтований на забезпечення соціальної справедливості, яка розуміється у широкому сенсі. Але сучасна модель більше націлена не на перерозподіл благ, про який ідеться у традиційній моделі, а на створення реальних умов для менш заможних верств населення забезпечити себе гідним доходом завдяки трудовій діяльності. Сучасні умови роблять усе менш популярним використання «скандинавської похибки» (коли складні проблеми бідності та соціальних негараздів намагаються вирішити, «заливаючи» їх грошима та «лікуючи симптоми» проблеми, замість знаходження та виправлення саме причин соціальних проблем ${ }^{23}$ ). Але знову ж таки лише інститут держави здатен виконувати таку «неефективну» діяльність, як забезпечення соціальної справедливості: саме механізми моделі «держави загального добробуту» дозволяють мати кожному громадянину універсальну «страховку» як від негараздів, які можна передбачити (безробіття, тимчасова втрата працездатності, ДТП, хвороба тощо), так і негараздів, виникнення яких оцінюють як малоймовірні (стихійні лиха та природні катаклізми, війни, техногенні аварії, пандемії тощо). Ринкові механізми самі по

${ }^{23}$ Ерік С. Райнерт. Як багаті країни збагатіли... і чому бідні країни лишаються бідними. Київ : Темпора. 2018. 452 с. 
собі не здатні ефективно вирішити як перелічені проблеми загалом, так і забезпечити ту саму соціальну справедливість, про яку йдеться.

5) Підтримка впродовж усього життя. Про необхідність державної підтримки громадян упродовж усього їхнього життя говорилось ще на початку становлення традиційної моделі «держави загального добробуту». У відомій доповіді У. Беверіджа «Соціальне страхування та інші види соціального обслуговування» (1942) (відомої як Beveridge Report), яка розпочинала еру визнання welfare state як провідної моделі, йшлося про піклування про громадянина «від колиски до труни» (“from the cradle to the grave") 24 . Сучасне розуміння соціально-економічних процесів дозволило конкретизувати, в якому напрямі і як саме така підтримка впродовж життєвого циклу повинна відбуватись. Зокрема, йдеться про державну підтримку дітей (надання їм медичної допомоги та освіти, забезпечення першочерговими потребами), державне пенсійне страхування та медичне страхування громадян. Протягом життя люди стикаються 3 багатьма іншими базовими потребами, наприклад, забезпечення належного житла, отримання вищої освіті та перекваліфікації громадян у зв'язку зі структурними зрушеннями в економіці. Неоліберальна теорія просто припускає, що ринкові механізми самі по собі, за рахунок «спонтанного порядку», пропонують найбільш ефективний спосіб забезпечення цих життєво важливих потреб, принаймні на базовому рівні. У деяких випадках і в деяких країнах та за деяких обставин це може бути правдою. Але важливо підкреслити, що це може бути правдою не в будь-яких обставинах, тому участь у цих процесах держави $\epsilon$ необхідною, як мінімум, як спостерігача та регулятора.

6) Розподіл труднощів між поколіннями. Незалежно від того, які наявні компроміси або взаємодоповнення між державним втручанням та ринковою саморегуляцію, $є$ деякі види розподілу негараздів, які ринок не може вирішити, але держава здатна це зробити. Обмін труднощами між поколіннями є одним з таких випадків. Громадяни в межах одного покоління можуть «об'єднувати» свої негаразди, але неможливо, щоб людина уклала контракт з ким-небудь з покоління, яке ще не народилося. Проте суспільство загалом може укладати такі соціальні контракти. I так відбувається весь час. Деякі витрати на участь у Першій світовій війні та Другій світовій війні були понесені наступними поколіннями. Інший приклад - це застосування концепції «сталого розвитку», що передбачає забезпечення балансу між задоволенням сучасних потреб людства і захистом інтересів майбутніх

${ }^{24}$ William Beveridge. Social Insurance and Allied Services. London: The Parliament, 1942. $47 \mathrm{p}$. 
поколінь. Добре продумані механізми «держави загального добробуту» дозволяють полегшити подібний розподіл негараздів між поколіннями.

Наведений огляд меж сучасної соціально-економічної моделі дозволяє чітко визначити її три основні функції:

1. Економічна функція:

- модель забезпечує стійкість економічної системи, усуваючи «провали ринку» та зменшуючи негативні наслідки від економічних «шоків»;

- модель стимулює економічне зростання: збільшується внутрішній попит та інноваційність економіки;

- економіка країни стає більш гнучкою та готовою до структурних перетворень.

Тут доречно зазначити, що, як показує практика, країни з вищими соціальними витратами розвиваються швидше. Якщо модель держави загального добробуту ретельно продумана та націлена на те, щоб дати працівникам другий шанс (як у скандинавських країнах), то вона може сприяти економічному зростанню, спонукаючи людей бути готовими до змін і тим самим полегшуючи структурні перетворення в країні ${ }^{25}$.

2. Соціальна функція (іноді в літературі ï називають «захисною функцією»):

- підтримка громадян, які опинились у скрутних соціальноекономічних умовах;

- зменшується кількість та ступінь негараздів, з якими стикається населення (бідність, безробіття, злочинність, медичні ризики тощо);

- створюються реальні умови для реалізації рівних можливостей громадян ${ }^{26}$;

- забезпечує соціальну мобільність громадян (що тісно пов'язано 3 економічною функцією, яка стимулює економічне зростання за рахунок соціальної мобільності).

3. Інтеграційна функція, яка робить суспільство єдиним, солідарним, а громадянина відповідальним членом цього суспільства. Країна, у якій забезпечений принцип соціальної справедливості, отримає суттєві внутрішньосистемні переваги. Адже люди не народжуються у вакуумі: соціально-економічне середовище, в якому вони живуть, надає суттєві обмеження на те, що вони можуть робити, і на те, що вони хочуть робити ${ }^{27}$.

\footnotetext{
${ }^{25}$ Чанг Х.-Ю. 23 приховані факти про капіталізм. Київ : Наш Формат, 2018. 296 с.

${ }^{26}$ Там само.

${ }^{27}$ Там само.
} 


\section{3. Механізми та інструменти сучасної держави загального добробуту}

Трансформація соціально-економічної моделі держави загального добробуту та переосмислення іï функцій призвели й до зміни iii механізмів та інструментів. Тенденція змін цих механізмів включає в себе такі напрями:

- все більшу тенденцію до універсалізації соціальних витрат;

- пошук варіантів кращої інтеграції інструментів та узгодженості політики між соціальними, економічними та екологічними аспектами розвитку;

- більш інклюзивні форми участі в розробці та реалізації політики;

- нові форми партнерства держави, громадського суспільства та бізнесу;

- нові напрями в глобальній та регіональній соціальній політиці.

У період «кризи» моделі держави загального добробуту іiі критики зосереджували увагу насамперед на економічному чиннику іiі використання: значні соціальні витрати урядів та соціальні відрахування бізнесу. «Архітектори» сучасного варіанту моделі «держави загального добробуту» стверджують, що в сучасних умовах соціальні видатки потрібно розглядати насамперед як соціальні інвестиції. Такі тенденції вказують, що відбулась еволюція моделі від «держави, що захищає» до «держави, що підсилює» (держави, що надає можливості $)^{28}$.

Прояв цього підходу можна побачити у сучасних програмах країн ЄС та самої євроспільноти загалом: усе більше ресурсів уряди країн зосереджують на реалізації проєктів у сфері освіти, впровадження підходу «навчання впродовж життя» (Life-long learning), інвестицій у людський капітал (особливо програми «ранньої підтримки дітей» (Early childhood care) тощо. Таким чином, відбувається «виправдовування» перерозподілу у економіці: не витрати бюджету на «соціальне проїдання», а інвестиції у майбутнє. Бачення подібного «виправдовування» соціальних видатків зображено схематично у табл. 1, яка показує вплив соціальних інвестицій на посилення економічних можливостей країни.

${ }^{28}$ Begg I., Mushövel F., Niblett R. The welfare state in Europe: visions for reform. Redesigning European welfare states. Ways forward. Chatham House, 2015. P. 29. 
Таблиця 1

«Виправдовування» соціальних видатків

\begin{tabular}{|c|c|c|}
\hline $\begin{array}{c}\text { Напрями соціальних } \\
\text { інвестицій }\end{array}$ & Результати політики & $\begin{array}{c}\text { Наслідки для } \\
\text { економічного життя }\end{array}$ \\
\hline \multirow{4}{*}{$\begin{array}{l}\text { Програми «ранньої } \\
\text { підтримки дітей», } \\
\text { дошкільна освіта } \\
\text { громадян, активна } \\
\text { політика на ринку } \\
\text { праці, інвестиції в } \\
\text { освіту, забезпечення } \\
\text { умов «навчання } \\
\text { впродовж життя» }\end{array}$} & \multirow{2}{*}{$\begin{array}{l}\text { Нові можливості для } \\
\text { робочої сили: нові } \\
\text { навички, гнучкість, } \\
\text { пристосованість до } \\
\text { швидких змін } \\
\end{array}$} & $\begin{array}{l}\text { Більша продуктивність } \\
\text { робочої сили }\end{array}$ \\
\hline & & $\begin{array}{l}\text { Більша частка інновацій } \\
\text { в економіці }\end{array}$ \\
\hline & \multirow{2}{*}{$\begin{array}{l}\text { Нова якість робочої } \\
\text { сили: інклюзивність, } \\
\text { активність, здатність } \\
\text { до самореалізації }\end{array}$} & $\begin{array}{l}\text { Менше нерівності та } \\
\text { менше «захисних» } \\
\text { соціальних витрат }\end{array}$ \\
\hline & & $\begin{array}{l}\text { Більша база для } \\
\text { оподаткування та більше } \\
\text { податкових зборів }\end{array}$ \\
\hline
\end{tabular}

Такий підхід вказує на те, що у розвинутих країнах, які запровадили модель «держави загального добробуту», спостерігається тренд від патерналізму держави до інклюзивного розвитку громадян.

Характерною рисою сучасної моделі $є$ й те, що немає ідеологічної прихильності до кращого способу вирішення проблем, 3 якими стикається держава. Незалежно від того, чи функціонує «держава загального добробуту» через державне забезпечення або державне регулювання та втручання на ринках, це не важливо, якщо модель $\epsilon$ ефективною. В деяких обставинах еволюція ринку (іноді внаслідок стимулюючого впливу уряду) зменшує величину або змінює характер втручання держави у систему суспільного добробуту. Це зумовлює різноманітні практики, що використовуються у моделі ${ }^{29}$.

Деякі країни, що раніше застосовували згадувану модель, модернізують або посилюють іiі механізми залежно від того, як вони визначають проблеми та можливості для їх вирішення. Вважається, що скандинавські країни мають класичну модель держави загального добробуту; але, як не дивно, є кілька країн, що розвиваються, такі як Намібія, Маврикій і Сейшели, які також мають певні механізми держави загального добробуту, які адаптовані до їхнього суттєво нижчого рівня життя. Ці країни застосовують модель для досягнення широкого кола соціальних цілей, включаючи економічне зростання, та вони багато чого змогли досягти (бо мають показники, що значно вищі за середні для рівня Африки), і багато хто в цих країнах приписує принаймні частину цього успіху своїй моделі держави загального

${ }^{29}$ Stiglitz J.E. The Welfare State in the Twenty-First Century. Working Papers of Roosevelt Institute; Climate and Economic Transformation. 2017. June, 20. 
добробуту. 3 іншого боку, деякі країни, включаючи США, мають значно обмежений соціальний захист, наприклад для чоловіків без дітей. Система соціальної безпеки для них - це лише заходи, щоб запобігти ї голодуванню, але сама система не призначена для того, щоб дати їм можливість жити з гідністю або дати їм можливості стати самодостатніми ${ }^{30}$.

Варто додати, що сучасні соціально-економічні моделі не існують у «чистому» вигляді і містять у собі елементи інших моделей ${ }^{31}$. Наприклад, у всіх моделях наявні певні інвестиції в інфраструктуру, хоча у моделі держави загального добробуту більше зосереджено уваги на соціальних витратах з глибоким всебічним аналізом того, які бонуси для суспільства створюються. Тобто у цій моделі такі соціальні інвестиції значно більші, про що йшлося вище ${ }^{32}$. $€$ також схожість сучасної моделі держави загального добробуту з моделлю мінімальної держави, в якій уряд втручається в процеси функціонування ринкової системи 3 метою підвищення іiі ефективності та забезпечення ефективного функціонування ринків ${ }^{33}$.

3 огляду на це більш доцільним видається розглядати не конкретні приклади механізмів та інструментів сучасної моделі, а тенденцію та напрям їх змін. Серед конкретних прикладів та трендів трансформації механізмів та інструментів сучасної моделі держави загального добробуту можна виділити такі:

1. Організаційні зміни забезпечення суспільних благ та соціальних сервісів: від централізованого перерозподілу та універсального покриття ризиків до децентралізації забезпечення соціальних благ та адресної допомоги. Це призводить до того, що місцевий рівень влади починає відігравати ключову роль у виконанні соціальної функції держави $^{34}$. Серед прикладів подібних тенденцій - Німеччина, Скандинавські країни, Нідерланди, Канада. У цих країнах традиційно розвинута система місцевого самоврядування забезпечує визначальний обсяг (здебільшого до 90\%) витрат на соціальне забезпечення.

30 Stiglitz J.E. The Welfare State in the Twenty-First Century. Working Papers of Roosevelt Institute; Climate and Economic Transformation. 2017. June, 20.

31 Романченко В.Б. Порівняльний аналіз сучасних соціально-економічних моделей держави. Інвестииї: практика та досвід. 2020. № 19-20. С. 186-199.

${ }^{32}$ Stiglitz J.E. The Welfare State in the Twenty-First Century. Working Papers of Roosevelt Institute; Climate and Economic Transformation. 2017. June, 20.

33 Романченко В.Б. Порівняльний аналіз сучасних соціально-економічних моделей держави. Інвестииії: практика та досвід. 2020. № 19-20. С. 186-199.

34 Большакова Ю.М. Основные тенденции в предоставлении государственных услуг в социальной сфере в условиях кризиса государства всеобщего благоденствия. Власть. 2014. Том. 22. № 6. С. 170-175. 
2. Використання моделі держави загального добробуту $\epsilon$ елементом політики, спрямованої на стимулювання економічного зростання за рахунок інновацій та людського капіталу. Інвестування в знання та вміння набуває все більшої значущості для економічного зростання та обміну плодами цього зростання. Перерозподіл доходів також сприяє економічному зростанню; наприклад, можливість дозволити собі правильне харчування покращує результати навчання ${ }^{35}$. Це пояснює значні витрати, які країни ОЕСР спрямовують на освітні програми, перекваліфікацію, підтримку молоді тощо.

3. Спроба запровадження в багатьох країнах універсального базового доходу - регулярну виплату певної суми грошей кожному члену певного співтовариства 3 боку держави або іншого інституту (виплати проводяться всім членам спільноти, незалежно від рівня доходу і без необхідності виконання роботи). Стверджується, що основний дохід - набагато простіша і прозоріша система соціального забезпечення, ніж та, яка існує сьогодні в державах загального добробуту в усьому світі. Замість численних програм соціального забезпечення впроваджується універсальний безумовний дохід. Стратегія введення базових доходів суперечлива, оскільки деякі прихильники базових доходів стверджують, що іiі слід додати до наявної системи соціального забезпечення, а не до іiі заміни. Спроби запровадити такий підхід на рівні соціального експерименту або державної програми були в Канаді, Фінляндії, Італії, Німеччині, Іспанії, Нідерландах, що говорить про характерний тренд спроби модернізації соціальної політики.

4. Переоцінка ролі індивідуальних внесків у сучасній моделі держави загального добробуту. Очевидно, що виплати на основі заробітної плати повинні передбачати внески. Проте, якщо першочерговою метою виплат є страхування (в охороні здоров'я) або скорочення бідності (в гарантованих виплатах), внески, що здійснюються працівником через роботодавця, не тільки менш ефективні, ніж у минулому, але також можуть позбавляти стимулу до зайнятості в офіційному секторі. Таким чином, медичне забезпечення i аналогічні пільги, можливо, краще фінансувати за рахунок оподаткування з більш широкою базою або за рахунок виділеного джерела доходів, який не пов'язаний зі статусом зайнятості, наприклад,

35 Барр Н. Смена течений. В условиях глубоких социальных изменений государство всеобщего благосостояния необходимо, как никогда прежде. Финансы и развитие : ежеквартальный журнал МВФ. 2018. Декабрь. С. 16-19. 
за рахунок частини надходження від податку на споживання (або «сировинного податку», який пропонували ввести в Україні) ${ }^{36}$.

5. Залучення нових акторів соціальної політики. В умовах скорочення соціальних зобов'язань держави переосмислюється роль ключових агентів соціальної політики, в тому числі зростає інтерес до діяльності інститутів самоорганізації громадян. Інститути самоорганізації громадян виступають у ролі суб'єктів соціальної політики, партнерів держави у формуванні та здійсненні соціальної політики. Теорія держави загального добробуту отримує подальший розвиток, з'являються нові моделі соціальної політики, що включають діяльність організацій третього сектору як додатковий вимір моделі держави загального добробуту. «Welfare State стає динамічним i прогресивним Welfare mix, об'єднуючим можливості і здатності різних інститутів, акторів і сфер сучасного суспільства» ${ }^{37}$.

6. Зміна підходів щодо урядування та управління державними активами. Зокрема, йдеться про намагання у багатьох країнах світу здійснити системний підхід щодо володіння та управління державними підприємствами: створення державних холдингових компаній, які виводяться від безпосереднього впливу політиків та державних органів. Тим самим є намагання, по-перше, відійти від дискусії «чи потрібна приватизація»; по-друге, підвищити якість послуг населенню; по-третє, переключити увагу та ресурси від короткострокових витрат на довгострокові інвестиції ${ }^{38}$.

\section{ВИСНОВКИ}

У статті було визначено, що в сучасному світі модель «держави загального добробут»є витребуваною. Стверджується, що віджила себе не сама концептуальна ідея моделі «держави загального добробуту», а іiі конкретна історична форма.

Сучасна соціально-економічна модель «держави загального добробуту» - це модель, яка спрямована на всебічний розвиток кожного громадянина завдяки ефективному розподілу стандартних (фінансово-матеріальних) i нетипових благ (культурних, політичних,

36 Барр Н. Смена течений. В условиях глубоких социальных изменений государство всеобщего благосостояния необходимо, как никогда прежде. Финансы и развитие : ежеквартальный журнал МВФ. 2018. Декабрь. С. 16-19.

37 Сидорина Т.Ю. Партнерство государства и институтов самоорганизации граждан в реализации социальной политики (теоретический аспект). Terra Economicus. 2010. № 8 (1). C. 117-129.

38 Деттер Д., Фьольстер С. Державне багатство народів, або Як управління державними активами може посилити чи підірвати економічне зростання. Львів : Видавництво Старого Лева. 2018. 328 с. 
екологічних), що забезпечується синергією ринкового саморегулювання та державного втручання.

Головними функціями сучасної моделі є:

- економічна, яка дозволяе уникати «провалів ринку» та стимулювати економічне зростання для всіх (інклюзивність економічного розвитку) за допомогою інновацій та інвестицій у людський капітал;

- захисна або соціальна, яка спрямована на соціальний захист, здійснення соціальних інвестицій, забезпечення соціальної мобільності та становлення соціальної справедливості у державі;

- інтеграційна функція, яка робить суспільство єдиним, консолідованим та солідарним, а громадянина відповідальним членом цього суспільства.

У розвинутих країнах, які запровадили модель «держави загального добробуту», спостерігається тренд від патерналізму держави до інклюзивного розвитку громадян. Це зумовило перехід від механізмів, які були спрямовані на перерозподіл («скандинавська похибка») до механізмів, які роблять громадян самодостатніми для самостійного вирішення їхніх життєвих проблем. Така трансформація зумовила, що сучасна модель починає використовувати нові підходи, які або замінюють старі механізми та інструменти, або їх модернізують. Зокрема, йдеться про децентралізацію забезпечення соціальних благ, перехід до адресної допомоги, спроби запровадити універсальний безумовний дохід як сучасний механізм соціального забезпечення, нові підходи до управління державними активами, залучення нових акторів соціальної політики, активну політику на ринку праці (в тому числі регулювання відносин у нетрадиційних формах зайнятості, таких як гігекономіка та самозайнятість) та інші.

\section{АНОТАЦІЯ}

У статті була проаналізовано конфігурацію сучасної соціальноекономічної моделі держави загального добробуту, а також визначені іiі основні функції та механізми, які дозволяють їх виконувати. У вступі до статті було показано, що сучасні виклики лише посилюють потребу у державі загального добробуту. У першій частині було висвітлено зміну концепції «держави загального добробуту», яка раніше здебільшого розглядалась з боку дихотомії «держава проти ринку», та 3 часом трансформувалась у принцип: «дії держави та ринку мають підсилювати один одного». У другій частині статті визначено основні функції сучасної соціально-економічної моделі держави загального добробуту: економічну, соціальну (захисну), інтеграційну. В другій частині також були наведені шість важливих напрямів, на які сучасна 
держава загального добробуту має значно більший вплив порівняно із традиційною моделлю. У третій частині статті показані зміни у механізмах сучасної держави загального добробуту, які визначають еволюцію моделі від «держави, що захищає» до «держави, що підсилює» (держави, що надає можливості). Це відображено у переході від механізмів, які були спрямовані на перерозподіл («скандинавська похибка») до механізмів, які роблять громадян самодостатніми для самостійного вирішення їхніх життєвих проблем.

\section{ЛІТЕРАТУРА}

1. Романченко В.Б. Порівняльний аналіз сучасних соціальноекономічних моделей держави. Інвестиції: практика та досвід. 2020. № 19-20. C. 186-199. DOI: 10.32702/2306-6814.2020.19-20.186.

2. Сидорина Т.Ю. Партнерство государства и институтов самоорганизации граждан в реализации социальной политики (теоретический аспект). Terra Economicus. 2010. № 8 (1). С. 117-129.

3. Чулицкая Т. Демонтаж государства всеобщего благосостояния. Палітычная сфера. 2005. № 4. С. 61-67.

4. Сидорина Т.Ю. Операция "Welfare State": решило ли государство всеобщего благосостояния проблемы идеального государства? Terra Economicus. 2012. № 10 (3). С. 84-99.

5. Stiglitz J.E. The Welfare State in the Twenty-First Century. Working Papers of Roosevelt Institute; Climate and Economic Transformation. 2017. June, 20. URL: https://rooseveltinstitute.org/wp-content/uploads/ 2020/07/RI-Welfare-State-21st-Century-201706.pdf.

6. Русаков В.М., Саранчин Ю.К. Социальное государство: кризис или закат? Современные исследования сочиальных проблем. 2012. № 11 (19). URL: https://cyberleninka.ru/article/n/sotsialnoe-gosudarstvokrizis-ili-zakat/viewer.

7. Фомін С.С. Типи соціально-економічних моделей та їхній вплив на процеси модернізації. Краӥни пострадянського простору: виклики модернізаиії : зб. наук. пр. 2016. С. 32-46.

8. Барр Н. Смена течений. В условиях глубоких социальных изменений государство всеобщего благосостояния необходимо, как никогда прежде. Финансы и развитие : ежеквартальный журнал МВФ. 2018. Декабрь. С. 16-19.

9. Стиглиц Д., Сен А., Фитусси Ж.-П. Неверно оценивая нашу жизнь: Почему ВВП не имеет смысла? Доклад Комиссии по измерению эффективности экономики и социального прогресса. Москва : Изд-во Института Гайдара. 2016. 216 с. 
10. Koch M. Sustainable Welfare, degrowth and eco-social policies in Europe. Social Policy in the European Union: State of Play. Bruxelles : European Trade Union Institute. 2018. P. 35.

11. Чанг Х.-Ю. 23 приховані факти про капіталізм. Київ : Наш Формат, 2018. 296 с.

12. Ерік С. Райнерт. Як багаті країни збагатіли... і чому бідні країни лишаються бідними. Київ : Темпора. 2018. 452 с.

13. Beveridge W. Social Insurance and Allied Services London : The Parliament, 1942. $47 \mathrm{p}$.

14. Begg I., Mushövel F., Niblett R. The welfare state in Europe: visions for reform. Redesigning European welfare states. Ways forward. Chatham House, 2015. P. 29.

15. Большакова Ю.М. Основные тенденции в предоставлении государственных услуг в социальной сфере в условиях кризиса государства всеобщего благоденствия. Власть. 2014. Том. 22. № 6. C. $170-175$.

16. Деттер Д., Фьольстер С. Державне багатство народів, або Як управління державними активами може посилити чи підірвати економічне зростання. Львів : Видавництво Старого Лева. 2018. 328 с.

Information about the author: Romanchenko V. B., Postgraduate Student at the Department of Economic Policy and Governance National Academy for Public Administration under the President of Ukraine 20, Antona Tsedika str., Kyiv, 03057, Ukraine 